\title{
PENGARUH KUALITAS PRODUK TERHADAP PEMBELIAN KEMBALI MOTOR HONDA BEAT SPORTY PADA DEALER HONDA CV. ANUGERAH PERDANA 4 YOS SUDARSO
}

\author{
Ni Nyoman Duwi Yuhani \\ Ponirin \\ Program Studi S1 Jurusan Manajemen, Fakultas Ekonomi dan Bisnis, Universitas Tadulako \\ Email: ninyomanduwiyuhani03@gmail.com; ppaidjan@gmail.com
}

\begin{abstract}
This research aims at finding out the product quality toward the repurchase of Honda Beat Sporty motor at Dealer Honda CV. Anugerah Perdana 4 Yos Sudarso. This was a causal descriptive. The research population was all the customers buying Honda Beat Sporty motor at Dealer Honda CV. Anugerah Perdana 4 Yos Sudarso. The samples were taken through purposive sampling with the number of the respondents was 60 . This research used multiple linear regression analysis. The results of this research can be known from product quality variables, consisting of: motor performance (XI), durability (X2), compliance with specifications (X3), the features (X4), and impression of quality (X5) give significant influence toward the repurchase of Honda Beat Sporty motor at Dealer Honda CV. Anugerah Perdana 4 Yos Sudarso with the value of significance 0.000 lower than $<0.05$. Based on the partial test ( $t$ test) it is found that product quality variable $(X)$ consisting of performance $(X 1)$ gives significant influence with value of significance 0.007, durability (X2) gives significant influence with value of significance 0.009, compliance with specifications (X3) gives significant influence with value of significance 0.047, the features (X4) gives significant influence with value of significance 0.022 and impression of quality (X5) gives significant influence with value of significance 0.009. It can be concluded that the total influence of product quality toward the repurchase of Honda Beat Sporty (adjusted $R^{2}$ ) is 53.5 percent.
\end{abstract}

Keywords: Product Quality, Repurchase

\begin{abstract}
Abstrak
\end{abstract}
Tujuan dari penelitian ini adalah untuk mengetahui pengaruh kualitas produk terhadap pembelian kembali motor Honda Beat Sporty Pada Dealer Honda CV. Anugerah Perdana 4 Yos sudarso. Jenis penelitian ini meliputi deskriptif kausal. Populasi yang digunakan dalam penelitian ini adalah seluruh konsumen yang membeli motor Honda Beat Sporty Pada Dealer Honda CV. Anugerah Perdana 4 Yos Sudarso. Teknik penarikan sampel menggunakan Porposive Sampling dengan jumlah sampel sebanyak 60 responden. Alat analisis yang digunakan pada penelitian ini adalah Analisis Regresi Linear berganda. Adapun hasil dari penelitian ini dapat diketahui dari variabel kualitas produk yang terdiri dari kinerja (X1), Daya Tahan (X2), kesesuaian dengan spesifikasi (X3), fitur (X4) dan kesan kualitas (X5) secara serempak berpengaruh signifikan terhadap pembelian kembali motor Honda Bear Sporty pada Dealer Honda CV. Anugerah Perdana 4 Yos Sudarso dengan nilai signifikan 0,000 di bawah $<0,05$. Dari hasil Pengujian secara parsial (uji t) ditemukan hasil variabel kualitas produk (X) yang terdiri dari kinerja (X1) berpengaruh signifikan dengan nilai 0,007, daya tahan (X2) berpengaruh signifikan dengan nilai 0,009 , kesesuaian dengan spesifikasi (X3) berpengaruh signifikan dengan nilai 0,047, fitur (X4) berpengaruh signifikan dengan nilai 0,022 dan kesan kualitas (X5) berpengaruh signifikan dengan nilai 0,009 . signifikan terhadap pembelian kembali. Besarnya pengaruh kualitas produk terhadap pembelian kembali (adjusted $\mathrm{R}^{2}$ ) adalah 53,5\%.

Kata kunci: Kualitas Produk, Pembelian Kembali

\section{PENDAHULUAN}

\section{Latar Belakang}

Persaingan di dunia industri semakin gencar dan kompetitif dimana suatu perusahaan berlomba-lomba untuk meluncurkan produk atau jasa yang terbaik untuk dapat menguasai pasar. Pengusaha akan berusa menguasai pangsa pasar dengan berbagai teknik untuk mencapai laba. 
Salah satu industri yang berpengaruh dalam perkembangan globalisasi yaitu industri sepeda motor motor. Hal ini muncul berbagai macam produk motor yang diproduksi oleh industri sepeda motor. Alat transportasi yang paling umum digunakan saat ini adalah sepeda motor dari pada alat transportasi umum lainnya dikarenakan penggunaan motor yang sangat mudah, luwes, irit cepat dan efisien dalam berpergian pada suatu tempat agar terhindar dari kemacetan lalu lintas. CV Anugerah Perdana 4 Yos Sudarso selalu menjual produk motor yang mempunyai kualitas baik, keunggulan dan harga yang ditawarkan relatif murah dibandingkan motor lainnya yang ditawarkan oleh pesaing. Motor Honda Beat Sporty merupakan motor yang berjenis matic yang paling banyak digemari oleh masyarakat kota Palu.

Kualitas produk yang terdiri dari kinerja, daya tahan, kesesuaian dengan spesifikasi, fitur dan kesan kualitas mempunyai pengaruh terhadap keputusan pembelian dalam (Permatasari:2016).

Konsumen akan lebih merasa puas jika hasil penilaian mereka menunjukkan bahwa barang yang mereka gunakan mempunyai mutu ketika pelanggan merasa puas akan menimbulkan minat beli ulang (Lupiyoadi dalam Mulyani 2015:58).

CV. Anugerah Perdana 4 Yos Sudarso sebagai Dealer otomotif di Sulawesi Tengah yang sedang mulai berkembang selalu memberikan harapan dan keyakinan bagi pengguna sepeda motor.

Pasca penelitian yang dilakukan peneliti melakukakan observasi wawancara awal peneliti dengan salah satu responden terkait dengan kualitas produk yang terdiri dari kinerja, daya tahan, kesesuaian dengan spesifikasi dan kesan kualitas motor ini banyak diminati konsumen karena kebanyakan konsumen membeli motor Honda ini karena harga yang sesuai dengan kualitas produknya. Disamping itu memiliki kinerja yang cukup baik sangat mudah digunakan dan dilihat dari daya tahan yaitu umur motor yang tahan lama meskipun motor ini terkadang mengalami kerusakan kecil pada saat penggunaan tergantung dari pemakainya. Fenomena saat ini yang terjadi dilapangan kualitas motor Honda ini banyak diminati konsumen meskipun motor ini banyak memiliki kekurangan atau masih tertinggalnya teknologi dibandingkan jenis motor Honda Lainnya yang telah memiliki teknologi terbaru.

Beberapa penelitian terdahulu yang menjadi acuan dalam penelitian ini yang terkait mengenai kualitas produk yaitu antara lain penelitian Aditi dan Hermansyur (2018) dengan judul Pengaruh Atribut Produk, Kualitas Produk dan Promosi Terhadap Keputusan Pembelian Mobil Merek Honda di Kota Medan. Hasil dari variabel atribut produk, kualitas produk dan promosi secara serempak berpengaruh signifikan terhadap keputusan pembelian. Atribut produk, kualitas produk dan promosi secara parsial berpengaruh signifikan terhadap keputusan pembelian. Penelitian Rahayu dan Haryonto (2017) dengan judul Pengaruh Kualitas Produk Terhadap Keputusan Pembelian Pada Majalah Media Asuransi (Studi Kasus PT. Asuransi Indonesia). Hasil dari penelitian ini didapatkan bahwa terdapat hubungan yang cukup kuat antara kualitas produk terhadap keputusan pembelian yang artinya kualitas produk memiliki pengaruh yang signifikan terhadap keputusan pembelian. Penelitian Pasaribu, Veta (2018) dengan judul Analisis Pengaruh Promosi, Kualitas Produk dan Desain Kemasan Terhadap Keputusan Pembelian Hand and Body Lotion merek Citra (Studi Kasus Carrefour Pamulang, Tangerang Selatan). Hasil penelitianya menunjukkan bahwa promosi, kualitas produk dan desain kemasan secara serempak berpengaruh secara signifikan terhadap keputusan pembelian. Uji parsial juga menunjukkan bahwa variabel kualitas desain kemasan paling berpengaruh secara signifikan terhadap keputusan pembelian. Penelitian Amrullah, Siburian dan Zainurossam (2016) dengan judul Pengaruh Kualitas Produk Dan Kualitas Layanan Terhadap Keputusan Pembelian Sepeda Motor Honda. Hasil dari penelitian menunjukkan bahwa variabel kualitas produk dan kualitas layanan berpengaruh positif dan signifikan terhadap keputusan pembelian. Penelitian Nugrahanto, Farida dan Listyorini (2015) dengan judul Pengaruh Kualitas 
produk dan Kesadaran Merek Terhadap Keputusan Pembelian Ulang Melalui Kepuasan Konsumen (Studi Konsumen PT. Mataram Sakti Setia Budi). Hasil penelitian ini menunjukkan bahwa kualitas produk memiliki pengaruh yang signifikan terhadap kepuasan konsumen dan kepuasan konsumen mempengaruhi keputusan pembelian ulang.

Penelitian ini dilakukan di CV. Anugerah Perdana 4 Yos Sudarso yang bertempat di jalan Yos Sudarso Kota Palu. Alasan peneliti mengambil penelitian ini karena motor Honda Beat Sporty selalu mengalami penjualan terbanyak dibandingkan jenis motor lainnya dan Dealer CV. Anugerah Perdana merupakan salah satu Dealer Honda yang penjualanya cukup tinggi dibandingkan dengan Dealer Honda lain yang ada di Kota Palu.

\section{KAJIAN LITERATUR}

\section{Bauran Pemasaran}

Menurut Zeithami dan Bitner dalam Babun (2016:84) marketing mix adalah elemen-elemen suatu organisasi yang dapat diawasi oleh suatu organisasi yang dapat digunakan untuk pemuasan atau komunikasi dengan pelanggan.

Menurut pendapat Philip Kotler dalam Rangkuti (2004:17) Marketing Mix atau bauran pemasaran adalah kumpulan alat-alat yang digunakan oleh perusahaan dalam memasarkan barang dan jasa dalam rangka untuk mencapai tujuan memasarkan sesui dengan target pasar sasaran sebelumnya yang telah ditetapkan. Dari defenisi di atas dapat ditarik kesimpulan bauran pemasaran adalah strategi pemasaran yan digunakan untuk menggabungkan beberapa elemen di dalam marketing mix itu sendiri.

\section{Kualitas Produk}

Sebelum membahas kualitas produk terlebih dahulu akan dijelaskan defenisi produk menurut ahli: menurut Cravens dalam Adam (2010:39) menyatakan bahwa produk merupakan segala seluruh sesuatu yang memiliki nilai dari suatu sasaran pasar dimana kemampuan dari produk tersebut mampu memberikan manfaat dalam memuaskan harapan yang di dalamnya termasuk barang dan jasa. Jadi produk adalah berupa barang dan jasa yang mempunyai manfaat dan nilai bagi pengguna dan memuaskan kebutuhan.

Kualitas produk menurut Durianto dalam Permatasari (2016:120) Produk adalah segala suatu pegerak yang memperagakan fungsi dalam memuaskan pelanggan yang paling utama sebuah produk dan kualitas produk merupakan dimensi yang paling global. Kualitas produk merupakan hal yang sangat penting harus diperhatikan harus diperhatikan oleh suatu perusahaan sebagai inti agar dapat bersaing dipasaran dan dapat memuaskan kebutuhan dan keinginan konsumen.

\section{Dimensi Kualitas Produk}

Menurut Durianto dalam permatasari (2016:13) ada lima dimensi dari kualitas produk:

1. Kinerja, berhubungan dengan karakteristik operasi dasar dari sebuah produk kinerja merupakan gambaran salah satu karakteristik atau fungsi utama dari suatu produk yang akan dibeli. Kinerja ini merupakan sebagai alat pertimbangan utama membeli suatu produk.

2. Daya tahan, adalah ukuran ketahanan dari sebuah produk dan berapa lama umur produk itu bias bertahan sebelum produk tersebut harus diganti. Semakin frekuensi penggunaan pemakaian konsumen terhadap produk semakin besar daya tahan produk.

3. Kesesuaian dengan spesifikasi mengenali tentang sejauh mana karakteristik operasi dasar dari sebuah produk untuk memenuhi spesifikasi tertentu dari konsumen atau tidak ditemukannya cacat pada produk. 
4. Fitur merupakan karakteristik dari suatu produk yang dibuat untuk lebih menyempurnakan manfaat dan fungsi dalam suatu produk atau menambah karakteristik pembeli terhadap suatu produk.

5. Kesan kualitas adalah probabilitas bahwa produk akan berkerja dengan memuaskan atau tidak dalam priode tertentu. Kesan kualitas pada produk dapat dirasakan oleh konsumen. Jadi semakin kecil bila terjadi kerusakan pada produk berarti produk tersebut dapat diandalkan.

\section{Pembelian kembali}

Menurut Andre dalam Putri (2017:12) pembelian kembali merupakan salah satu keinginan pembeli untuk menggunakan atau memakai kembali produk yang sama dimasa yang akan datang. Menurut Hawkins dalam Caraka (2015:131) mengartikan pembelian kembali sebagai salah satu kegiatan membeli ulang yang dapat dilakukan oleh konsumen terhadap suatu produk dengan merek yang sama tanpa harus diikuti oleh perasaan yang berarti terhadap produk tersebut. Jadi kesimpulan dari pembelian kembali merupakan salah satu perilaku setelah pembelian yang didasari oleh kepuasan terdapat kemungkinan yang menyebabkan seorang untuk melakukan pembelian kembali karena konsumen akan merasa puas akan produk atau jasa yang mereka gunakan untuk melakukan pembelian kembali.

Menurut Peter dan Olsen dalam Ariani Maulida (2007:281) mengartikan pembelian ulang adalah kegiatan membeli yang pernah dilakukan lebih dari satu kali atau beberapa kali.

Menurut Kotler dan Keller (2008:242) terdapat beberapa faktor yang dapat menjadi pengaruh konsumen dalam pembelian kembali yaitu:

1. Faktor internal yaitu faktor yang ada di dalam diri konsumen yang terdiri kepercayaan dan sikap konsumen terhadap produk atau jasa.

2. Faktor eksternal (faktor penganggu) sikap orang lain serta situasi tempat pembelian.

Dari penjelasan di atas dapat disimpulkan konsumen akan berminat melakukan pembelian kembali jika suatu barang atau jasa nilai yang ditawarkan suatu produk atau jasa yang memiliki nilai yang sangat baik.

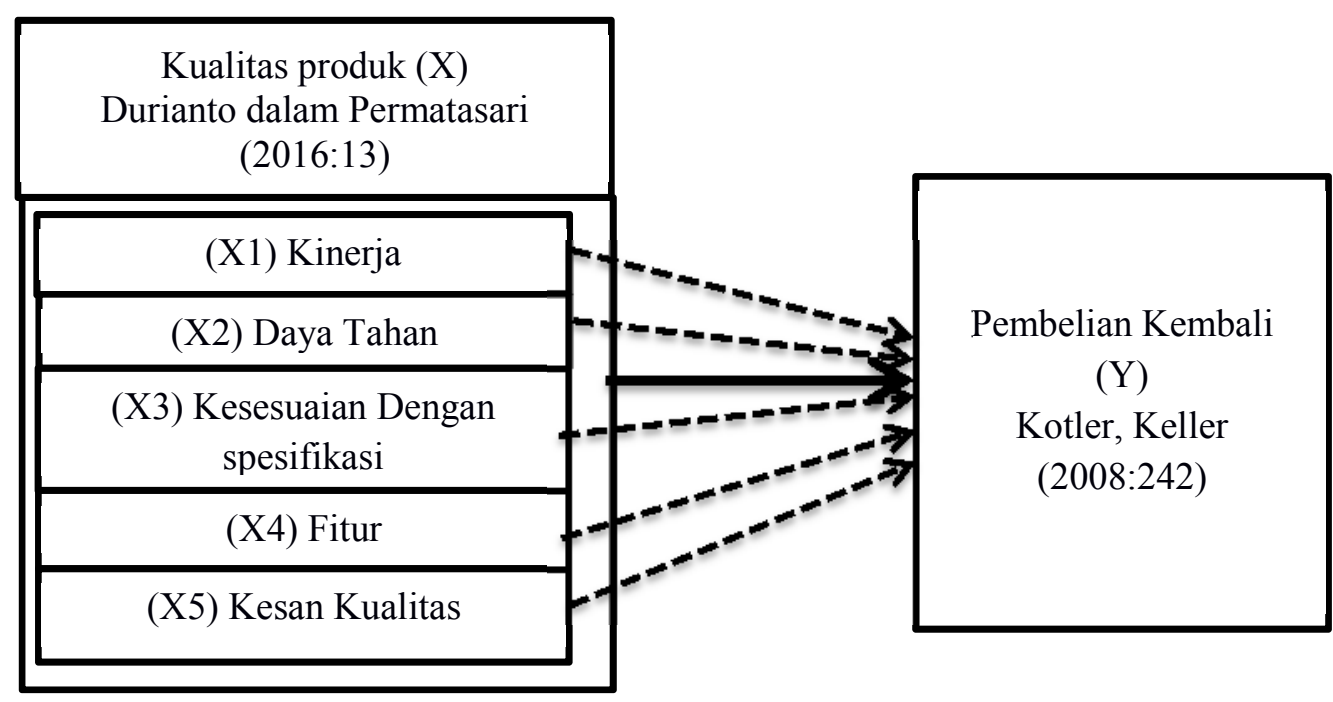

Gambar 1 Kerangka Pemikiran

\section{METODE PENELITIAN}

\section{Jenis Penelitian}


Jenis penelitian yang digunakan dalam penelitian ini adalah jenis penelitian deskriptif kausal yang dilakukan untuk memperoleh gambaran tentang pengaruh variabel kualitas produk terhadap pembelian kembali.

\section{Lokasi Penelitian}

Lokasi pada penelitian ini bertempat di jalan Yos Sudarso pada CV. Anugerah Perdana 4 Yos Sudaso di Kota Palu.

\section{Jenis dan Sumber Data}

Penelitian ini menggunakan dua jenis data yaitu data kuantitatif merupakan data yang disajikan berupa dalam bentuk angka-angka atau jenis data dalam jumlah satuan. Data kualitatif adalah data yang bersifat informasi. Sementara sumber data yang digunakan dalam penelitian ini adalah Data primer, yaitu data yang diperoleh secara langsung dari responden melalui observasi, wawancara serta hasil kuesioner. Data sekunder, yaitu data yang diperoleh melalui studi pustaka dengan cara mempelajari literatur-literatur yang mempunyai kaitan dengan penelitian ini berupa buku, makalah, majalah, jurnal dan data yang diperoleh dari pihak CV. Anugerah Perdana 4 Yos Sudarso dan artikel lainnya.

\section{Populasi dan sampel}

Populasi dalam penelitian ini adalah konsumen yang telah melakukan pembelian kendaraan motor Honda Beat sporty. Maka populasi dalam penelitian ini pada dasarnya tidak diketahui secara pasti jumlahnya. Sampel menurut Sugiyono (2014:81) sampel adalah bagian dari jumlah dan karakteristik yang dimiliki oleh populasi tersebut. Mengingat jumlah populasi tersebut yang tidak dapat diketahui secara pasti, maka sampel yang ditetapkan 60 responden. Penentuan sampel ini merujuk pada teori yang dikemukakan oleh Sugiyono (2014:91) memberikan saran-saran yaitu jumlah anggota sampel minimal 10 kali dari jumlah variabel yang diteliti berjumlah (5 variabel independen +1 variabel dependen). Maka jumlah anggota sampel 10 x 6 yaitu 60 responden. Jumlah tersebut telah dianggap telah memadai untuk dijadikan sampel penelitian pendapat Roscoe dalam Sugiyono (2014:90) ukuran sampel yang layak pada penelitian ini adalah antara 30 hingga 500 .

\section{Teknik penarikan sampel}

Teknik penarikan sampel yang digunakan dalam penelitian ini adalah teknik penarikan sampel purposive sampling yaitu berdasarkan pertimbangan kriteria tertentu Sugiyono $(2014 ; 85)$.

\section{Teknik pengumpulan data}

Teknik pengumpulan data yang digunakan dalam penelitian ini adalah pengamatan, penyebaran kuesioner kepada responden dan melakukan Wawancara kepada para responden.

\section{Instrumen Penelitian}

Untuk menguji instrumen penelitian, maka peneliti melakukan uji instrumen terlebih dahulu pada Dealer Honda CV. AP 7 di jalan Dewi Sartika Kota Palu dengan jumlah responden sebanyak 40 responden yaitu untuk dapat mengetahui apakah kuesioner yang digunakan dalam penelitian ini valid dan reliabel.

\section{Teknik Analisis Data}

Penelitian ini adalah penelitian kuantitatif maka data yang akan diperoleh dari responden melaui kuesioner dikodekan sesuai dengan skala Likert 1-5, dan kemudian menggunakan tabulasi dengan analisis statistik dan menggunakan program SPSS. Program SPSS, kemudian setelah data terkumpul akan dianalisis dengan uji validitas dan reliabilitas. Intrumen penelitian, uji asumsi klasik dan analisis Regresi Linear berganda.

\section{Uji Asumsi Klasik}


Beberapa uji asumsi klasik yang perlu dilakukan dalam penelitian ini, yaitu terdapat empat jenis uji asumsi klasik yaitu uji normalitas, uji multikolinearitas, dan uji heteroskedastisitas.

\section{Analisis Regresi Linear Berganda}

Analisis Regresi Linear Berganda ini dapat digunakan dalam mengetahui seberapa besar pengaruh variabel independen terhadap variabel dependen. Data diolah menggunakan bantuan SPSS 21 persamaan regresi sebagai berikut:

$$
\begin{aligned}
& \mathbf{Y}=\alpha+\mathbf{b}_{1} \mathbf{X}_{\mathbf{1}}+\mathbf{b}_{2} \mathbf{X}_{\mathbf{2}}+\mathbf{b}_{3} \mathbf{X}_{\mathbf{3}}+\mathbf{b}_{\mathbf{4}} \mathbf{X}_{\mathbf{4}}+\mathbf{b}_{\mathbf{5}} \mathbf{X}_{\mathbf{5}}+\mathbf{e} \\
& \text { Ket: Y1 }=\text { Pembelian kembali } \\
& \text { X2 }=\text { Kinerja } \\
& \text { X3 }=\text { Daya tahan } \\
& \text { X4 }=\text { Kesesuaian dengan spesifikasi } \\
& \text { X5 }=\text { Fitur } \\
& \alpha=\text { Konstanta } \\
& \text { B1-b 2 }=\text { Koefisien regresi } \\
& \text { e }=\text { Kesalahan (error) }
\end{aligned}
$$

\section{Uji Simultan atau (Uji F)}

Uji simultan ini digunakan untuk mengetahui ada atau tidaknya pengaruh signifikan secara sama-sama (serempak) variabel independen terhadap variabel dependen:

1. Jika nilai (signifikan $\mathrm{F}<\alpha=0,05$ ) yang artinya berpengaruh signifikan pada tingkat kepercayaan 95\%, maka terbukti bahwa semua faktor bebas $(\mathrm{X})$ berpengaruh bersama-sama secara nyata (signifikan) terhadap faktor terikat Y (pembelian kembali).

2. Jika nilai (signifikan $\mathrm{F}>\alpha=0,05$ ) pada tingkat kepercayaan $95 \%$ maka, terbukti bahwa semua faktor bebas $(\mathrm{X})$ tidak berpengaruh serempak secara nyata (signifikan) terhadap faktor terikat $\mathrm{Y}$ (pembelian kembali).

\section{Uji Parsial (Uji t)}

Uji parsial digunakan untuk mengetahui pengaruh masing-masing faktor bebas secara parsial terhadap faktor terikat.

1. Jika probabilitas (signifikan $\mathrm{t}<\alpha=0,05$ ) artinya pada tingkat kepercayaan $95 \%$, maka terbukti secara parsial faktor bebas $\mathrm{X}$ (kualitas produk) berpengaruh secara nyata (signifikan) terhadap faktor terikat Y (pembelian kembali).

\begin{tabular}{|c|c|c|c|c|c|}
\hline \multirow{3}{*}{ Variabel Dependen } & \multirow{2}{*}{\multicolumn{3}{|c|}{$\begin{array}{c}\text { Unstandardized } \\
\text { Coefficients } \\
\text { Standardized } \\
\text { coefficients }\end{array}$}} & \multirow{3}{*}{$\mathbf{T}$} & \multirow{3}{*}{ Sig } \\
\hline & & & & & \\
\hline & B & Std. Error & Beta & & \\
\hline (Constant) & 1,884 & 2,197 & & & \\
\hline Kinerja $\left(\mathrm{X}_{1}\right)$ & 0,313 & 0,112 & 0,315 & 2,806 & 0,007 \\
\hline Daya tahan $\left(\mathrm{X}_{2}\right)$ & 0,349 & 0,129 & 0,301 & 2,711 & 0,009 \\
\hline
\end{tabular}

2. Jika probabilitas (signifikan $\mathrm{t}>\alpha=0,05$ ) artinya pada tingkat kepercayaan $95 \%$ maka terbukti secara parsial faktor bebas X (kualitas produk) tidak berpengaruh secara nyata terhadap faktor terikat $\mathrm{Y}$ (pembelian kembali).

\section{HASIL DAN PEMBAHASAN Uji Validitas dan Reliabilitas}

Tabel 1

Berdasarkan Uji Regresi Linier Berganda Variabel Dependen: Pembelian Kembali 


\begin{tabular}{|c|c|c|c|c|c|c|}
\hline \multicolumn{2}{|c|}{$\begin{array}{l}\text { Kesesuaian dengan Spesifikasi } \\
\left(\mathrm{X}_{3}\right)\end{array}$} & 0,215 & 0,106 & 0,222 & 2,029 & 0,047 \\
\hline \multicolumn{2}{|c|}{ Fitur $\left(\mathrm{X}_{4}\right)$} & 0,327 & 0,139 & 0,289 & 2,357 & 0,022 \\
\hline \multicolumn{2}{|l|}{ Kesan Kualitas $\left(\mathrm{X}_{5}\right)$} & $-0,316$ & 0,117 & $-0,299$ & $-2,705$ & 0,009 \\
\hline Konstanta & $: \mathbf{1 , 8 8 4}$ & & & & & \\
\hline R Square & : 0,465 & & & F Hitung & : 9,376 & \\
\hline $\mathbf{R}$ & $: 0,682^{\mathrm{a}}$ & & & Sig & : 0,000 & \\
\hline Adjusted R Square & $: 0,415$ & & & & & \\
\hline
\end{tabular}

Sumber: data diolah tahun (2019)

Berdasarkan Tabel 2 di atas, persamaan regresi yang diperoleh adalah sebagai berikut:

$Y=1.884+0,313 X_{1}+0,349 X_{2}+0,215 X_{3}+0,327 X_{4}-0,316 X_{5}+e$

Pembahasan:

1. Nilai konstanta sebesar 1,884 memberikan arti bahwa pada saat variabel independen (kinerja, daya tahan, kesesuaian dengan spesifikasi, fitur dan kesan kualitas) bernilai Nol (0), maka pembelian kembali motor Honda Beat Sporty pada Dealer Honda CV. Anugerah Perdana 4 Yos Sudarso oleh konsumen sebesar 1,884.

2. Nilai koefisien variabel kinerja $\left(X_{1}\right)$ sebesar 0,313 dapat diartikan bahwa setiap pertambahan variabel kinerja akan menyebabkan meningkatnya pembelian kembali motor Honda Beat Sporty pada Dealer Honda CV. Anugerah Perdana 4 Yos Sudarso Sedangkan variabel lainnya konstan.

3. Nilai koefisien variabel daya tahan $\left(\mathrm{X}_{2}\right)$ sebesar 0,349 dapat diartikan bahwa setiap pertambahan variabel daya tahan akan menyebabkan meningkatnya pembelian kembali motor Honda Beat Sporty pada Dealer Honda CV. Anugerah Perdana 4 Yos Sudarso Sedangkan variabel lainnya konstan.

4. Nilai koefisien variabel kesesuaian dengan spesifikasi $\left(\mathrm{X}_{3}\right)$ sebesar 0,215 dapat diartikan bahwa setiap pertambahan variabel kesesuaian dengan spesifikasi akan menyebabkan meningkatnya pembelian kembali motor Honda Beat Sporty pada Dealer Honda CV. Anugerah Perdana 4 Yos Sudarso Sedangkan variabel lainnya konstan.

5. Nilai koefisien variabel fitur $\left(\mathrm{X}_{4}\right)$ sebesar 0,327 dapat diartikan bahwa setiap pertambahan variabel fitur akan menyebabkan meningkatnya pembelian kembali motor Honda Beat Sporty pada Dealer Honda CV. Anugerah Perdana 4 Yos Sudarso Sedangkan variabel lainnya konstan.

6. Nilai koefisien variabel kesan kualitas $\left(\mathrm{X}_{5}\right)$ sebesar $-0,316$ dapat diartikan bahwa setiap pertambahan variabel kesan kualitas akan menyebabkan dan dapat meningkatnya pembelian kembali motor Honda Beat Sporty pada Dealer Honda CV. Anugerah Perdana 4 Yos Sudarso Sendangkan variabel lainnya konstan.

Nilai R Square (R2) sebesar 0,465 atau 46,5\% terhadap pembelian kembali motor Honda Beat Sporty pada Dealer Honda CV. Anugerah Perdana 4 Yos Sudarso. Sedangkan sisanya $(100 \%$ $46,5 \%=53,5 \%$ ) dijelaskan oleh sebab-sebab yang dari luar variabel yang tidak diteliti. 


\begin{tabular}{lrrrrr}
\hline Model & $\begin{array}{r}\text { Sum of } \\
\text { Squares }\end{array}$ & Df & Mean Square & F & Sig. \\
\hline 1. Regression & 36.527 & 5 & 7.305 & 9.376 &, $000^{\mathrm{b}}$ \\
Residual & 42.073 & 54 & 779 & & \\
Total & 78.600 & 59 & & & \\
\hline
\end{tabular}

Sumber: data diolah tahun 2019

Berdasarkan Tabel 2 didapatkan nilai signifikan F sebesar 0,000, yang artinya nilai tersebut lebih kecil jika dibandingkan dengan nilai signifikansi sebesar 0,05 . Oleh karena itu dapat disimpulkan bahwa variabel independen yang terdiri dari kinerja, daya tahan, kesesuaian dengan spesifikasi, fitur dan kesan kualitas secara serempak berpengaruh terhadap pembelian kembali motor Honda Beat Sporty pada Dealer Honda CV. Anugerah Perdana 4 Yos sudarso.

Pengujian Hipotesis (Uji t)

Tabel 3 Uji t

\begin{tabular}{cccc}
\hline & Model & $\mathrm{t}$ & Sig \\
\hline \multirow{3}{*}{1} & (Constant) & 0,858 & 0,395 \\
\cline { 2 - 4 } & $\mathrm{X}_{1}$ & 2,806 & 0,007 \\
\cline { 2 - 4 } & $\mathrm{X}_{2}$ & 2,711 & 0,009 \\
\hline $\mathrm{X}_{3}$ & 2,029 & 0,047 \\
\hline $\mathrm{X}_{4}$ & 2,357 & 0,022 \\
\hline & $\mathrm{X}_{5}$ & $-2,705$ & 0,009 \\
\hline
\end{tabular}

Sumber: data diolah tahun 2019

Adapun hasil pengujian secara parsial untuk variabel independen terhadap variabel dependen sebagai berikut:

1. Berdasarkan Tabel 3 dari hasil pengujian menggunakan SPSS didapatkan hasil angka signifikan $\mathrm{t}$ sebesar 007 angka $0,07<0,05$. Hal ini berarti terdapat pengaruh variabel kinerja terhadap terhadap pembelian kembali motor Honda Beat Sporty pada Dealer Honda CV. Anugerah Perdana 4 Yos Sudarso dengan besar pengaruh 0,313 maka dari itu hipotesis diterima.

2. Berdasarkan Tabel 3 dari hasil pengujian menggunakan SPSS didapatkan hasil angka signifikan t sebesar 009 angka $0,09<0,05$. Hal ini berarti terdapat pengaruh variabel daya tahan terhadap pembelian kembali motor Honda Beat Sporty pada Dealer Honda CV. Anugerah Perdana 4 Yos Sudarso dengan besar pengaruh 0,349 maka dari itu hipotesis diterima.

3. Berdasarkan Tabel 3 dari hasil pengujian menggunakan SPSS didapatkan hasil angka signifikan $\mathrm{t}$ sebesar 047 angka $0.47<0,05$ hal ini berarti terdapat pengaruh variabel kesesuaian dengan spesifikasi terhadap pembelian kembali motor Honda Beat Sporty pada Dealer Honda CV. Anugerah Perdana 4 Yos Sudarso dengan besar pengaruh 0,215 maka dari itu hipotesis diterima.

4. Berdasarkan Tabel 3 dari hasil pengujian menggunakan SPSS didapatkan hasil angka signifikan $t$ sebesar 022 angka $0,22<0,05$ hal ini berarti terdapat pengaruh variabel fitur terhadap pembelian kembali motor Honda Beat Sporty pada Dealer Honda CV. Anugerah Perdana 4 Yos Sudarso dengan besar pengaruh 0.215 maka dari itu hipotesis diterima.

5. Berdasarkan Tabel 3 dari hasil pengujian menggunakan SPSS didapatkan hasil angka signifikan t sebesar 009 angka $0,09<0,05$ hal ini berarti terdapat pengaruh variabel kesan 
kualitas terhadap pembelian kembali motor Honda Beat Sporty pada Dealer Honda CV.

Anugerah Perdana 4 Yos Sudarso dengan pengaruh -0,316 maka dari itu hipotesis diterima.

\section{Pembahasan}

Pengaruh Kualitas Produk Terhadap Keputusan Pembelian Kembali Motor Honda Beat Sporty Pada Dealer Honda CV. Anugerah Perdana 4 Yos Sudarso.

Hasil uji $\mathrm{F}$ yang telah terbukti bahwa variabel kualitas produk yang terdiri dari kinerja $\left(\mathrm{X}_{1}\right)$, daya tahan $\left(\mathrm{X}_{2}\right)$, kesesuaian dengan spesifikasi $\left(\mathrm{X}_{3}\right)$, fitur $\left(\mathrm{X}_{4}\right)$ dan kesan kualitas $\left(\mathrm{X}_{5}\right)$ secara serempak berpengaruh signifikan terhadap pembelian kembali motor Honda Beat Sporty pada Dealer Honda CV. Anugerah Perdana 4 Yos Sudarso. Hasil dari penelitian ini didukung oleh teori yang dikemukakan oleh Durianto dalam Permatasari (2016:13) kualitas produk adalah suatu pengerak yang memperagakan fungsi dan memuaskan pelanggan yang paling utama dalam sebuah produk dan kualitas produk merupakan dimensi yang paling global. Penelitian ini juga sama dengan penelitian yang dilakukan oleh Nugrahanto, Farida dan Listyorini (2015) yang diteliti berpengaruh terhadap pembelian ulang melalui kepuasan konsumen (Studi pada konsumen Yamaha Vixion PT. Mataram Sakti Setia Budi. Bahwa kualitas produk dan kesadaran merek secara serempak berpengaruh signifikan terhadap kepuasan konsumen mempengaruhi keputusan pembelian kembali.

Pengaruh Kinerja Terhadap Pembelian Kembali Motor Honda Beat Sporty Pada Dealer Honda CV. Anugerah Perdana 4 Yos Sudarso.

Berdasarkan uji t yang telah dilakukan hasil menunjukkan bahwa kinerja berpengaruh signifikan terhadap pembelian kembali kembali motor Honda Beat Sporty pada Dealer Honda CV. Anugerah Perdana 4 Yos Sudarso. Motor Honda Beat Sporty terkenal akan irit bahan bakar membuat konsumen membeli kembali salah satu keunggulan dari motor Honda Beat Sporty yang dirasakan konsumen adalah irit dalam bahan bakar sehingga konsumen merasa cocok memilih membeli motor Honda Beat Sporty sebagai alat transportasi untuk berpergian kesuatu tempat. Hasil dari penelitian ini didukung oleh teori yang dikemukakan oleh Durianto dalam Permatasari (2016;13) kinerja berhubungan dengan karakteristik operasi dasar dari sebuah produk dan kinerja juga merupakan gambaran salah satu karakteristik atau fungsi utama dari suatu produk yang akan dibeli. Kinerja ini merupakan sebagai alat pertimbangan utama untuk membeli suatu produk.

\section{Pengaruh Daya Tahan Terhadap Pembelian Kembali Motor Honda Beat Sporty Pada Dealer Honda CV. Anugerah Perdana 4 Yos Sudarso.}

Berdasarkan uji t yang telah dilakukan bahwa hasil menunjukkan bahwa variabel daya tahan berpengaruh signifikan terhadap pembelian kembali motor Honda Beat Sporty pada Dealer Honda CV. Anugerah Perdana 4 Yos Sudarso. Konsumen mengatakan bahwa daya tahan motor Honda Beat Sporty tidak mudah rusak tergantung dari perawatan motor meskipun motor ini sering digunakan. Motor Honda Beat Sporty dapat digunakan ditanjakan dan motor Honda Beat Sporty dapat digunakan lebih dari 6 tahun. Hasil dari penelitian ini didukung oleh teori yang dikemukakan oleh Durianto dalam Permatasari (2016:13) daya tahan adalah seberapa lama umur produk itu bisa bertahan sebelum produk tersebut harus diganti. Semakin besar frekuensi penggunaan pemakaian konsumen terhadap produk semakin besar daya tahan produk tersebut.

Pengaruh Kesesuaian Dengan Spesifikasi Terhadap Pembelian Kembali Motor Honda Beat Sporty Pada Dealer Honda CV. Anugerah Perdana 4 Yos Sudarso.

Berdasarkan uji t yang telah dilakukan hasil menunjukkan bahwa variabel kesesuaian dengan spesifikasi berpengaruh signifikan terhadap pembelian kembali motor Honda Beat Sporty pada Dealer Honda CV. Anugerah Perdana 4 Yos Sudarso. Sebagaimana indikator yang digunakan dalam penelitian ini adalah tampilan motor yaitu memiliki bentuk performa sesuai dengan 
keinginan harapan konsumen motor Honda Beat Sporty memiliki bentuk-bentuk kemampuan dan keunggulan yang dimiliki oleh motor tersebut agar bisa memberikan kepuasan kepada penggunanya. Hasil dari penelitian ini didukung oleh teori yang dikemukakan oleh Durianto dalam Permatasari (2016:13) kesesuaian dengan spesifikasi adalah sejauh mana karakteristik operasi dasar dari sebuah produk untuk memenuhi spesifikasi tertentu dari konsumen atau tidak ditemukanya cacat pada produk. Dari garansi yang diberikan lebih 1 tahun dapat menarik perhatian konsumen dalam melakukan pembelian kembali.

\section{Pengaruh Fitur Terhadap Pembelian Kembali Motor Honda Beat Sporty Pada Dealer Honda CV. Anugerah Perdana 4 Yos Sudarso.}

Berdasarkan hasil uji $\mathrm{t}$ yang telah dilakukan hasil menunjukkan bahwa variabel fitur berpengaruh signifikan terhadap pembelian kembali motor Honda Beat Sporty pada Dealer Honda CV. Anugerah Perdana 4 Yos Sudarso Motor Honda Beat Sporty ini memiliki desaian yang sangat baik yang menjadi tren sepeda motor yang menjadi pertimbangan kosumen dalam pembelian motor. Hasil dari penelitian ini didukung oleh teori yang dikemukakan oleh Durianto dalam Permatasari (2016:13) fitur merupakan karakteristik dari suatu produk yang dibuat untuk lebih menyempurnakan manfaat dan fungsi dalam suatu produk atau menambah karakteristik pembeli terhadap suatu produk. Dimensi fitur ini merupakan salah satu karakteristik utama suatu produk yang akan melengkapi manfaat dasar pada produk motor. Motor Honda Beat Sporty mempunyai banyak pilihan warna yang menarik mengikuti tren masa kini yang akan menarik perhatian konsumen untuk dapat melakukan pembelian kembali.

\section{Pengaruh Kesan Kualitas Terhadap Pembelian Kembali Motor Honda Beat Sporty Pada} Dealer Honda CV. Anugerah Perdana 4 Yos Sudarso.

Berdasarkan uji t yang telah dilakukan hasil menunjukkan bahwa variabel kesan kualitas berpengaruh signifikan terhadap pembelian kembali Motor Honda Beat Sporty pada Dealer Honda CV. Anugerah Perdana 4 Yos Sudarso. Sebagaimana indikator yang diajukan dalam penelitian ini hasil penelitian tanggapan responden mengenai harga motor Honda Beat Sporty sesuai dengan kualitasnya. Hasil dari penelitian ini didukung oleh teori yang dikemukakan oleh Durianto dalam Permatasari (2016:13) menyatakan bahwa kesan kualitas adalah probabilitas bahwa produk akan berkerja dengan memuaskan atau tidak dalam periode tertentu. Kesan kualitas dapat dirasakan oleh konsumen. Jadi semakin kecil bila terjadi kerusakan pada produk maka produk tersebut dapat diandalkan. Kesan kualitas sangat mempengaruhi pembelian kembali apabila kesan kualitas pada produk tidak baik maka konsumen akan berpikir untuk melakukan pembelian kembali begitu juga sebaliknya.

\section{Kesimpulan dan Saran}

\section{Kesimpulan}

Berdasarkan hasil analisis dan pembahasan yang telah dilakukan mengenai Pengaruh Kualitas Produk Terhadap Pembelian Kembali Motor Honda Beat Sporty Pada Dealer Honda CV. Anugerah Perdana 4 Yos Sudarso. Dapat disimpulkan sebagai berikut:

1. Kualitas Produk yang terdiri dari Kinerja, Daya Tahan, Kesesuaian Dengan Spesifikasi, Fitur dan Kesan Kualitas secara serempak berpengaruh signifikan terhadap pembelian kembali motor Honda Beat Sporty pada Dealer Honda CV. Anugerah Perdana 4 Yos Sudarso.

2. Kinerja berpengaruh signifikan terhadap pembelian kembali motor Honda Beat Sporty pada Dealer Honda CV. Anugerah Perdana 4 Yos Sudarso.

3. Daya Tahan berpengaruh signifikan terhadap pembelian kembali motor Honda Beat Sporty Pada Dealer Honda CV. Anugerah Perdana 4 Yos Sudarso. 
4. Kesesuaian Dengan Spesifikasi berpengaruh signifikan terhadap pembelian kembali motor Honda Beat Sporty pada Dealer Honda CV. Anugerah Perdana 4 Yos Sudarso.

5. Fitur berpengaruh signifikan terhadap pembelian kembali motor Honda Beat Sporty Pada Dealer Honda CV. Anugerah Perdana 4 Yos Sudarso.

6. Kesan Kualitas berpengaruh signifikan terhadap pembelian kembali motor Honda Beat Sporty pada Dealer Honda CV. Anugerah Perdana 4 Yos Sudarso.

\section{Saran}

Berdasarkan kesimpulan yang telah diuraikan sebelumnya, maka saran-saran yang diharapkan dapat menyangkut kegunaan penelitian dan dapat meningkatkan pembelian kembali pada Dealer Honda CV. Anugerah Perdana 4 Yos Sudarso adapun saran yang diberikan oleh penulis sebagai berikut:

1. Hasil dari penelitian ini diharapkan dapat menjadi bahan pertimbangan bagi Dealer CV. Anugerah Perdana dalam rangka meningkatkan pembelian kembali

2. Variabel kinerja, daya tahan, kesesuaian dengan spesifikasi, fitur kesan kualitas secara serempak dan parsial berpengaruh signifikan terhadap pembelian kembali motor Honda Beat Sporty pada Dealer Honda CV. Anugerah Perdana 4 Yos Sudarso. Dari itu perlunya sebagai bahan pertimbangan kepada pihak Dealer CV. Anugerah Perdana 4 Yos Sudarso, agar dapat kiranya mempertahankan dan meningkatkan kualitas produk yang telah terbentuk dengan baik agar dapat bertahan dalam persaingan dan kepada pihak perusahaan CV. Anugerah Perdana agar lebih memperhatikan variabel khususnya varibel kesesuaian dengan spesifikasi dengan idikator harga motor Beat Sporty lebih murah dibandingkan dengan jenis motor lainnya dan variabel kesan kualitas dengan indikator spare part motor Honda Beat Sporty tidak cepat rusak, oleh karena itu perusahaan harus lebih memberikan kesan kualitas yang baik sehingga dapat lebih meningkatkan pembelian kembali.

3. Kepada peneliti selanjutnya diharapkan melakukan kajian untuk dapat melibatkan variabel lain yang terkait dengan pengaruh kualitas produk terhadap pembelian kembali sehingga mendapatkan hasil dari kajian yang lebih maksimal.

\section{REFERENSI}

Adam, Rosida P. 2010. Manajemen Pemasaran. Palu: Lembaga Pengkajian Pembaharuan Hukum Dan kebijakan Publik (LP2HKP).

Ariani, Maulida. 2018. "Pengaruh Variasi Produk Terhadap Pembelian Ulang Pada Cafe Vin'z Ice Cream Di Kota Samarinda"Jurnal Administrasi Bisnis" 6 (1).

Aditi, Hermansyur. 2018. "Pengaruh Atribut Produk, Kualitas Produk Dan Promosi, Terhadap Keputusan Pembelian Mobil Merek Honda Di Kota Medan.” Jurnal Ilmiah Manajemen dan Bisnis 19 (1): 64-72.

Amrullah, Siburian, dan Zainurossam. 2016. "Pengaruh Kualitas Produk Dan Kualitas Layanan Terhadap Keputusan Pembelian Sepeda Motor Honda" Jurnal Ekonomi dan Manajemen 13 (2):20.

Babun, Suharto. 2016. Marketing pendidikan: Menata Ulang PTKI Menghadapi Pasar Bebas ASEAN. Yogyakarta: Pt LKIS Pelangi Aksara.

Caraka, Gilang Paradis. 2015. "Peranan Karakteristik Dan Psikologi Konsumen Terhadap Keputusan Pembelian Kembali Produk Pakaian Melalui Instagram” Jurnal Manajemen 2 (1):12.

Kotler, Philip dan Keller. 2008. Manajemen Pemasaran. Edisi 13 Jilid 1. Jakarta: Erlangga.

Mulyani, Zahara dan Santi. 2015. "Pengaruh Kualitas Produk Terhadap Minat Beli Ulang Lipstik Merek Wardah Pada Mahasiswi Universitas Tadulako" 1 (3). 
Malhotra, Neresh k. 2006. Riset Pemasaran: Pendekatan Terapan. Jilid 2. Jakarta: PT. Indeks.

Nugrahanto, Farida dan Listyorini. 2015. "Pengaruh Kualitas Produk Dan Kesadaran Merek Terhadap Keputusan Pembelian Ulang Melalui Kepuasan Konsumen (Studi Pada Konsumen Yamaha Vixion Pt. Mataram Sakti Setiabudi),” Jurnal Administrasi Bisnis 5 (1):9.

Permatasari, DI. 2016. "Pengaruh Kualitas Produk Terhadap Keputusan Konsumen Membeli Motor Honda Blade 110 cc Pada CV. Anugerah Perdana Palu. Skripsi Manajemen Fakultas Ekonomi Universitas Tadulako."

Putri dan Tanamal. 2017. "Pengaruh Kualitas Produk Dan Harga Terhadap Pembelian Kembali Produk Gosh Di Kota Palu Dengan Kepercayaan Merek Sebagai Variabel Antara (Studi Pada Mahasiswa Universitas Tadulako)" Jurnal Ilmu Manajemen Universitas Tadulako 3 (1):12.

Pasaribu, Veta. 2018. "Analisis Pengaruh Promosi, Kualitas Produk Dan Desain Kemasan Terhadap Keputusan Pembelian Hand Body Lotion Merek Citra (Studi Kasus Carrefour Pamulang, Tangerang Selatan)" Jurnal Pemasaran Kompetetif. Manajemen Pemasaran 1 (1):16.

Rahayu, dan Haryanto. 2017. "Pengaruh Kualitas Produk Terhadap Keputusan Pembelian Pada Majalah Media AsuransI” Jurnal Pemasaran Kompetetif. Manajemen Pemasaran 1: (1):13.

Rangkuti, Freddy. 2004. Flexibel Markerting. Jakarta: Gramedia Pustaka Utama.

Sugiyono. 2014. Metode Penelitian Kuantitatif Dan R\&D. Bandung: Alfabeta.

Sugiyono. 2017. Metode Penelitian Kuantitatif, Kualitatif Dan R\&D. Bandung: CV. Alfabeta. 